\title{
Poznatky z testování vybraných biochemických přípravků pro úpravu prostředí vodních prvků kulturních památek
}

\section{MILOŠ ROZKOŠNÝ, JOSEF KRATINA, HANA HUDCOVÁ, PAVEL SEDLÁČEK}

\author{
Klíčová slova: kulturní památky - historické zahrady - vodní prvky - biologické prípravky - kvalita vody
}

\section{SOUHRN}

Článek je zaměřen na prezentaci poznatků z testování vybraných biochemických přípravků pro úpravu prostředí vodních prvků historických zahrad a parků a kulturních památek. Cílem studie bylo experimentálně posoudit př́nos a rizika aplikace těchto prípravků, a to s ohledem na zlepšení kvality vody, omezení rozvoje řas a sinic v eutrofních podmínkách a snížení objemu dnového sedimentu. Studie byla provedena s využitím soustavy poloprovozních modelů okrasných bazénů a s prímou aplikací na reálných vodních prvcích zahrady zámku $\checkmark$ Libochovicích. Dosažené poznatky ukazují, že pravidelnou aplikací vybraných a vhodných biochemických prípravků, nejlépe od začátku sezony, lze udržet vhodnou kvalitu vodních prostředí, a to zejména u malých bazénů a nádrží. Součástí práce byla i analýza souboru vzorků sedimentů k určení potenciálu využití přípravků v širším měřítku. Tento potenciál byl potvrzen.

\section{ÚVOD}

\section{Proč se věnovat kvalitě prostředí vodních prvků}

a její udržení během návštěvnické sezony?

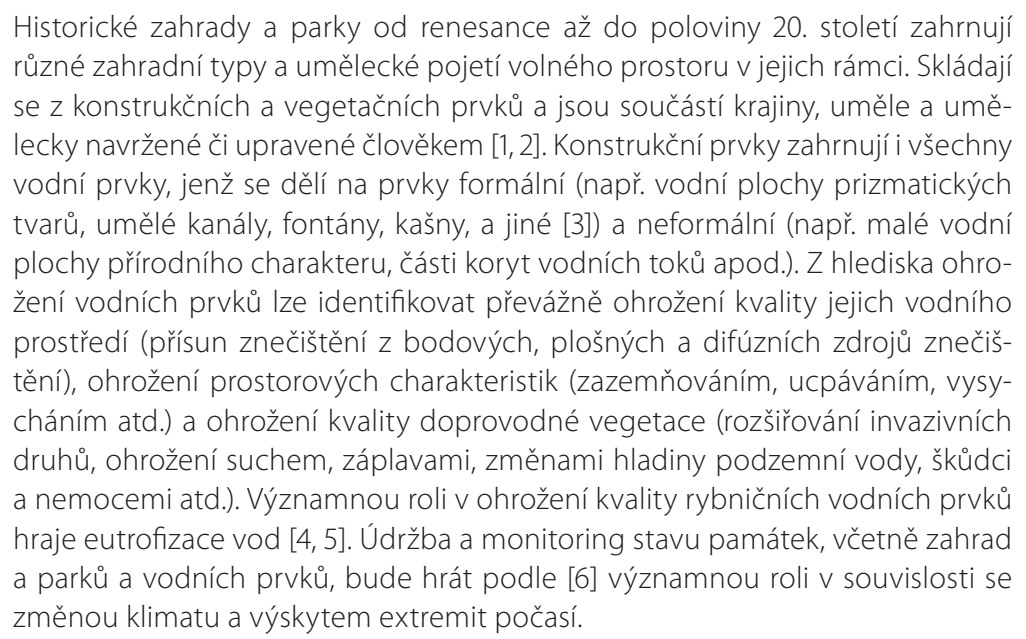

Historické zahrady a parky od renesance až do poloviny 20. století zahrnují různé zahradní typy a umělecké pojetí volného prostoru v jejich rámci. Skládají se z konstrukčních a vegetačních prvků a jsou součástí krajiny, uměle a umělecky navržené či upravené člověkem [1, 2]. Konstrukční prvky zahrnují i všechny vodní prvky, jenž se dělí na prvky formální (např. vodní plochy prizmatických tvarů, umělé kanály, fontány, kašny, a jiné [3]) a neformální (např. malé vodní plochy prírodního charakteru, části koryt vodních toků apod.). Z hlediska ohrožení vodních prvků Ize identifikovat převážně ohrožení kvality jejich vodního prostředí (prísun znečištění z bodových, plošných a difúzních zdrojů znečištění), ohrožení prostorových charakteristik (zazemňováním, ucpáváním, vysycháním atd.) a ohrožení kvality doprovodné vegetace (rozšiřování invazivních druhů, ohrožení suchem, záplavami, změnami hladiny podzemní vody, škůdci a nemocemi atd.). Významnou roli v ohrožení kvality rybničních vodních prvků hraje eutrofizace vod [4, 5]. Údržba a monitoring stavu památek, včetně zahrad změnou klimatu a výskytem extremit počasí.

\section{Možnosti ovlivnění kvality prostředí vodních prvků}

Ovlivnění kvality prostředí je možné jak osvědčenými a používanými postupy, tak i řízením biologických procesů. Používané postupy zahrnují recirkulaci a filtraci vody, což se uplatní spiše pro formální vodní prvky. Tato řešení jsou pro ně rozpracována např. v príručce [3]. Dále se jedná o manipulaci s vodou, její výměnu anebo zajištění dostatečného průtoku a ředění znečištění, tedy postupy využitelné pro formální i neformální vodní prvky. $V$ některých prípadech je možné $v$ rámci rekonstrukce změnit zdroj vody. U menších vodních prvků Ize ovlivnit, resp. omezit projevy eutrofizace vody, zákal, zbarvení vody, výskyt tzv. vodního květu, zarůstání, aplikací chemických prípravků pro ošetření anebo desinfekci vody. Zlepšení stavu může významně přispět odbahnění a samozřejmě řešení znečištění pritékajících vod a vnos splavenin úpravami v povodí, což pravděpodobně přesáhne vždy možnosti správy dané památkově chráněné lokality nebo objektu.

Specifická problematika množství, kontaminace a možností odstranění a uložení sedimentů vodních nádrží, v přeneseném významu i vodních prvků kulturních památek historických sídel, je celosvětovým problémem [7] a i v podmínkách České republiky je upravena legislativou (vyhláška č. 257/2009 Sb., o používání sedimentů na zemědělské půdě). V prípadě, že sediment kvalitou nesplňuje požadavky této vyhlášky, je nutné jeho uložení na skládky, což s sebou nese velké finanční prostředky. Proto je snahou řešit množství a i složení sedimentů pomocí jiných technologií, než je bagrování a následné deponování sedimentů [8-10]. Novými postupy, které se stále více uplatňují v praxi péče o vodní plochy, jezírka a koupací biotopy, je využití biochemie a biotechnologií spočívající v aplikaci biologicko-enzymatických prípravků, které mohou příznivě ovlivnit složení sedimentů a jejich množství [11, 12]. Pro studium vlastností prípravků a jejich účinností jsou využívány mikrobiologické metody, a to zejména stanovení počtu kultivovatelných mikroorganismů. Dále je možné sledovat změny koncentrací ukazatelů kvality vody (zejména obsah nutrientů) a složení biosestonu v návaznosti na kompetici bakterií s řasami [13].

\section{Cíl studie}

Cílem studie, provedené jako dílčí součást celého výzkumu kvality prostředí vodních prvkủ kulturních památek (objektů, rezervací a zón), bylo provést prověření a hodnocení stavu vodních prvků (fontán, kašen, bazénů, nádrží, rybníků apod.) památkově chráněných objektů a území a kvality jejich vodního prostředí, se zaměřením na všechny typy památkových rezervací, národní kulturní 
památky a lokality světového kulturního dědictví. Nejprve bylo třeba zvolit vhodné postupy, mezi něž patřilo využití dotazníkového šetření, detailního průzkumu vodního prostředí vybraných lokalit a analýz vzorků vod a sedimentů se zahrnutím rozboru vybraných biologických složek (fytoplankton, zooplankton, vegetace) a posouzení složení rybích obsádek. Výsledkem výzkumu by měla být doporučení a návrhy opatření k udržení či zlepšení kvality, včetně úprav rybích obsádek.

\section{METODIKA PRÁCE}

Práce na studii vycházely z výsledků detailního ročního sledování souboru pilotních lokalit výzkumného projektu. Níže je uveden soupis těchto lokalit a jejich mapové zobrazení (obr. 1).

Při terénních šetřeních byly pro vybrané vodní prvky (neformální i formální) přístroji Hach-Lange HQ40d měsičně měěeny: teplota vody, koncentrace rozpuštěného kyslíku, nasycení kyslíkem, elektrická konduktivita vody a pH. Měrení byla prováděna ve vrstvě vody pod hladinou a nade dnem. Průhlednost byla měřena Secchiho deskou. Odebrané vzorky vod byly analyzovány v akreditovaných laboratořích Vúv na obsah nerozpuštěných a organických látek, jednotlivé formy dusíku a fosforu, obsah vybraných iontů (chloridy, sírany, vápník, draslík atd.) umožňující přesnější poznání daného prostředí.

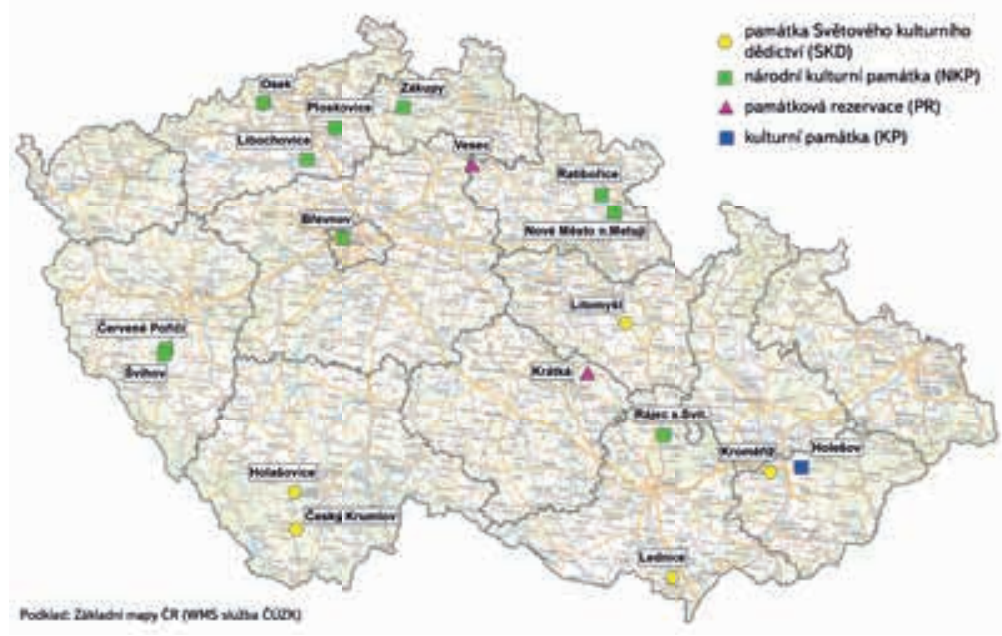

Obr. 1. Výzkumné lokality a jejich zařazení do kategorií památek

Fig. 1. Surveyed localities and their rank by culture heritage site categories

Popis sledovaných vodních prvků lokalit na obr. 1:

— průtočné rybníky bez produkčního chovu ryb - Břevnov, Červené Pořičí, Český Krumlov, Holašovice, Ploskovice, Vesec, Krátká, Rájec nad Svitavou (2 rybníčky), Kroměríž-Podzámecká zahrada (1 rybník), Lednice,

- průtočné rybníky s produkčním chovem ryb - Osek (1 rybník), KroměřížPodzámecká zahrada (2 rybníky), Holešov,

- větší bazény a nádrže s okrasnými rybami - Osek (3 nádrže), Ratibořice, Litomyšl, Rájec nad Svitavou (2 nádrže), Kroměříž-Květná zahrada,

- kašny, fontány a malé nádrže - Libochovice, Zákupy, Nové Město nad Metují,

- vodní príkop - Švihov.

Pro získání informací o společenstev osidlující vybrané vodní prvky jsme zvolili následující biologické metody. V prvé řadě se jednalo o stanovení chlorofylu-a. Tato metoda vychází z ČSN 757575 „Jakost vod - měření biochemických ukazatelů - spektrofotometrické stanovení. Koncentrace chlorofylu-a poskytuje informaci o množství a potenciální fotosyntetické aktivitě řas. Stanovení bylo doplněno určením koncentrace tzv. feopigmentů, což jsou produkty rozkladu fytoplanktonu a slouží jako indikace jeho fyziologického stavu, a to stanovením poměru chlorofylu k feopigmentům.

Dále to bylo stanovení trofického potenciálu, vycházející z normy TNV 757741 - Mikrometoda stanovení toxicity a trofického potenciálu řasovým testem. Trofický potenciál je ukazatelem obsahu biologicky využitelných živin ve vodě. Podstatou zkoušky je zjištění množství narostlé biomasy u zfiltrovaného vzorku, který se očkuje zkušebním organismem (v našem případě cenobiální zelená řasa Scenedesmus quadricauda) za standardních podmínek do stacionární fáze růstu. Zjištěné množství biomasy je prímo úměrné trofickému potenciálu udávaného v mg/l a udává trofii (úživnost) vody. Podrobněji např. [14]. Poslední použitou metodou bylo stanovení biosestonu - fytoplanktonu a planktonních sinic vycházející z ČSN 757712 „Kvalita vod. Biologický rozbor - stanovení biosestonu“ a ČSN 757717 „Kvalita vod. Stanovení planktonních sinic". Tato metoda pomáhá charakterizovat dané vodní prostředí, rámcově určit původ znečištění, živin a prípadně zátěže nejrůznějšího druhu. Tuto metodu jsme použili v krácené míře, kdy úroveň determinace nebyla postavená na prímé kvantifikaci jedinců (buněk) v $1 \mathrm{ml}$ původního vzorku, ale na procentickém zastoupení jednotlivých oddělení. Také byl kladen dưraz na přitomnost indikátorových druhů, které mohou signalizovat zhoršené změny.

Tyto uvedené postupy a analýzy byly využity jak při provozu a sledování vlivu aplikace vybraných prípravků v poloprovozním měřítku (nádrže v areálu VúV TGM v Praze Podbabě), v reálném měřítku (vodní prvky a areálu zámku Libochovice), tak v podstatě i při experimentech v laboratorních podmínkách, kdy byl stanovován potenciál různých prípravků k úpravě podmínek vodního prostředí, redukce prítomnosti fosforu anebo fytoplanktonu či redukci organické složky sedimentů.

Jelikož je možné biochemické prípravky využít i na úpravu vlastností a množství sedimentů, byla tato možnost ve studii také zkoušena a posouzena. Jejich aplikace vychází z potenciálu bakteriálního společenstva rozkládat organickou složku sedimentů, a tím snížit jejich množství a zejména objem. Pro studii byla využita datová sada obsahující 90 vzorků sedimentů odebraných z vodních prvků pilotních lokalit a rady dalších památkově chráněných objektů a areálů. Jednalo se tak o širokou škálu vodních prvků zahrnujících prakticky všechny typy těchto prvků vyskytující se v památkově cenných anebo i chráněných areálech České republiky. Sedimenty pocházely jak z jarních, tak i podzimních odběrů. Odběry byly prováděny Ekmanovým drapákem z člunu, prípadně z prostoru před odtokovým objektem, kde to bylo možné. $V$ prípadě mělkých, zejména formálních vodních prvků (např. okrasných bazénů) to nebylo možné a byl použit ruční sběr nádobou na tyči. Sedimenty byly zpracovány v laboratoři. Z provedených analýz byly pro účely studie využity analýzy sušiny a ztráty žíháním, tedy stanovení podílu spalitelné organické složky.

Co se týče metodiky práce s biochemickými a čistě biologickými přípravky, jejich předběžný výběr byl proveden na základě rešerše jejich komerční dostupnosti v oboru údržby okrasných nádrží a jezírek, jenž byl doplněn vývojem a testováním vhodné směsi ze základních surovin pro jejich přípravu (nosič biomasy - jemně mletý zeolit, nebo mouka; sušená bakteriální kultura a doplňkové živné soli a enzymy). Komerčně dostupné a testované přípravky např. zahrnovaly přípravky s obsahem měd'natých solí (inhibice růstu rass), hliníkových solí či hlinitokřemičitanových solí (využitelné pro srážení), např. na bázi látky PAX (polyaluminiumchlorid - viz http://www.prochemie.cz/chem/tech-list-pax-18-polyaluminiumchlorid.pdf), prípravky s obsahem extraktu z ječné slámy (výrobce Microbe-Lift), nebo rašeliny (resp. s obsahem rašelinného podílu s obsahem huminových látek, doplněný o živné enzymy a extrakt ječné slámy k inhibici růstu řas).

Experimentální fáze vycházela z doporučených koncentrací pro aplikaci přípravků na tisíc litrů vody, kdy byla aplikována jednorázově uvedená doporučená koncentrace a její dvojnásobné množství na stejný objem vody. Při následné aplikaci v poloprovozu a reálném provozu probíhalo dávkování níže uvedenými postupy. 


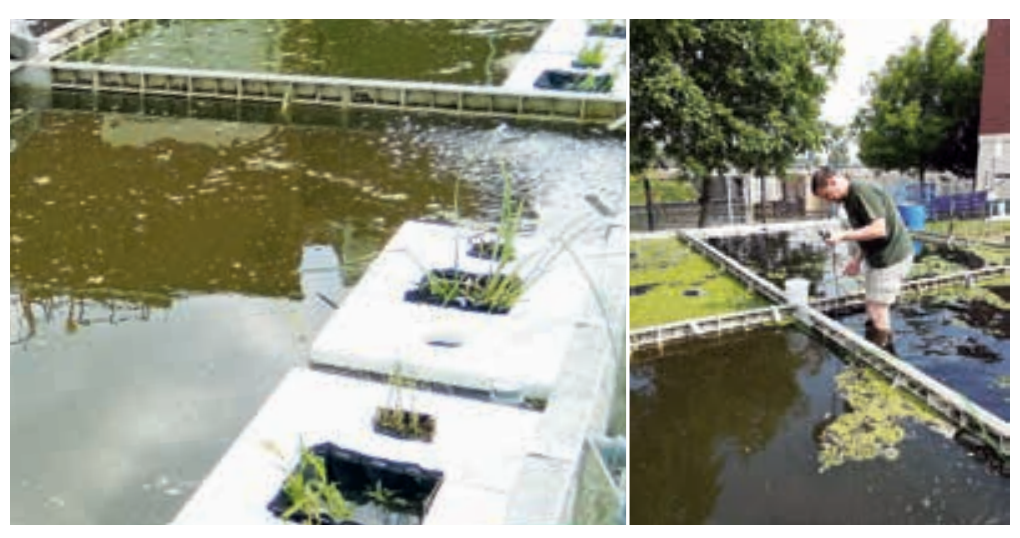

Obr. 2. Poloprovozní model okrasných vodních prvků historických zahrad

Fig. 2. Semi-operated models of historical garden ornamental water elements

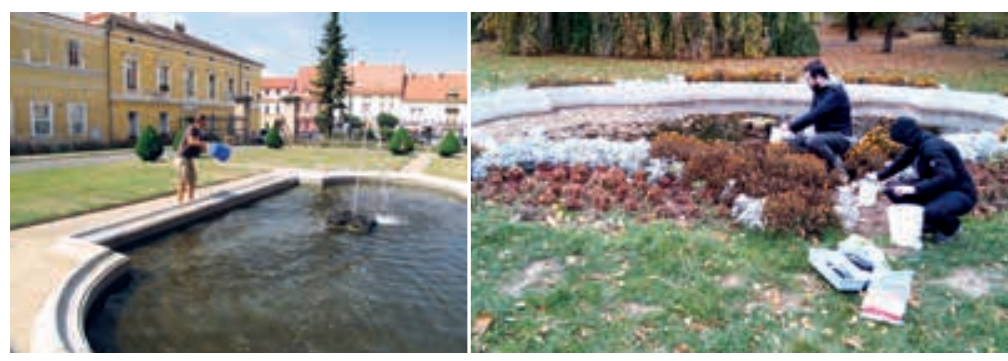

Obr. 3. Vodní prvky v areálu zámku Libochovice; aplikace roztoku biologického př́ipravku (vlevo) a měření parametrů kvality vody (vpravo)

Fig. 3. Libochovice chateau water elements; biological preparation solution application (left) and water quality parameters measuring (right)

\section{POPIS TESTOVACÍHO POLOPROVOZU A PILOTNÍ LOKALITY}

V areálu VúV TGM Praha byly $k$ dispozici mělké nádrže prizmatického tvaru se dnem a stěnami výšky cca $50 \mathrm{~cm}$ vyrobenými svařováním polypropylenových desek (obr. 2). Dvě z těchto nádrží byly využity jako poloprovozní modely okrasných formálních bazénů $\vee$ reálných klimatických podmínkách, napuštěné a doplňované reálnou říční vodou (zdrojovou vodou byla řeka Vltava $\checkmark$ Praze-Podbabě).

Nádrže mají následující parametry:

- menší bazény (označené H1 a K1): 3,40 m × 2,40 m, hloubka vody přibližně 0,40 m.

— větší bazény (označené H2 a K2): 3,40 m × 4,90 m, hloubka vody približně 0,40 m.

Bazény byly napouštěny $v$ dubnu daného roku a vypouštěny $v$ listopadu podle aktuálních teplot. Jejich provoz tedy odpovídal provozu reálných vodních prvků památkově chráněných areálů a objektů.

Aplikovaný biologický bakteriálně-enzymatický prípravek sestával ze směsi enzymů, živných solí, bakteriálních kmenů a zeolitového nosiče. Prípravek, spolu s několika dalšími byl podroben analýze v laboratoři, včetně provedení kultivačních testů. Přípravek byl skladován v uzavřené neprůhledné plastové nádobě při konstantní teplotě asi $20^{\circ} \mathrm{C}$ (v laboratoři, ve skladě), ne na prímém slunečním světle.

Průběh aplikace prípravku byl následující: Dávka př́pravku byla rozpuštěna $v$ desetilitrové nádobě (pro bazén K1, pro bazén K2 se využila pětilitrová konev) naplněné vodou z nádrže, do které byl prípravek následně aplikován (K1, K2). Reakční doba aktivace prípravku byla 15 až 20 minut. Během této doby byl objem vody $v$ konvi/kbelíku několikrát promícháván nekovovým predmětem, ideálně v intervalech 5 minut. Roztok pro prípravu byl následně dávkován
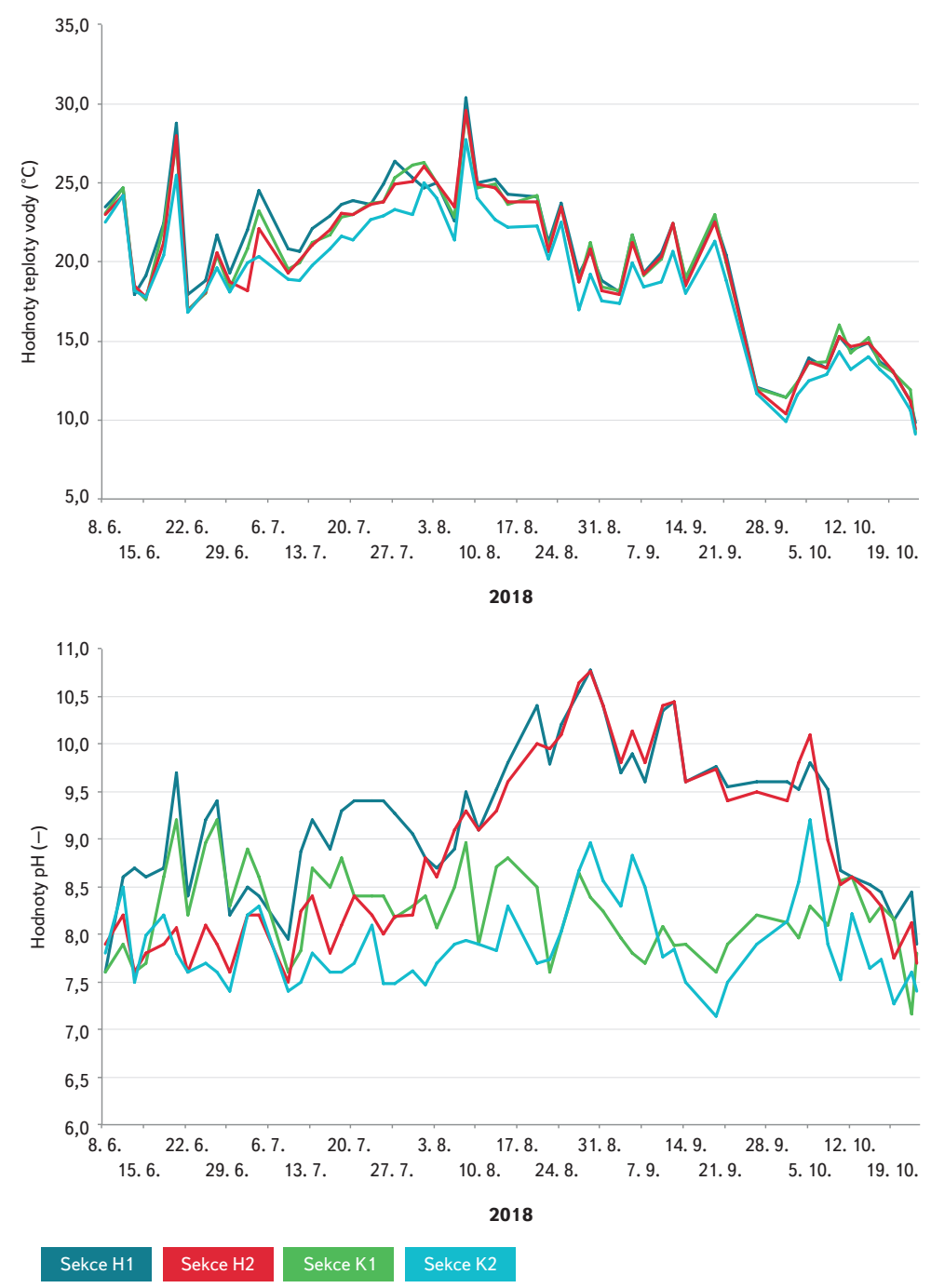

Obr. 4. Průběh teploty vody a hodnoty pH vody v sekcích poloprovozních modelových nádrží

Fig. 4. The course of water temperature and water $\mathrm{pH}$ in the sections of semi-operated model basins

do nádrží K1 a K2. Dávka prípravku byla stanovena na $50 \mathrm{~g}$ přípravku na 1 m³ vody $v$ bazénu, čemuž odpovídaly podle objemu bazénů následující dávky: $\mathrm{K} 1=3,264 \mathrm{~m}^{3} \Rightarrow$ dávka 122,5 g, K2 =6,664 $\mathrm{m}^{3} \Rightarrow$ dávka $250 \mathrm{~g}$. Dávkování do obou bazénů začalo v červnu 2018 a pokračovalo až do řína 2018 v týdenním kroku. V roce 2019 začalo dávkování opět v červnu a pokračovalo až do října.

Praktická část studie vlivu aplikace biologického bakteriálně-enzymatického přípravku byla prováděna v letech 2018 a 2019 v historické zahradě zámku Libochovice $(50.4051400 \mathrm{~N}, 14.0438403 \mathrm{E})$ pro tři vodní prvky. Dva malé okrasné bazény s pracovním označením LIB-1 (obr. 3 vlevo) a LIB-3 (obr. 3 vpravo) a jednu fontánu (pracovní označení LIB-2). Použit byl stejný prípravek jako $\vee$ prípadě poloprovozního modelu ve stejném dávkování a srovnatelným postupem aplikace. 


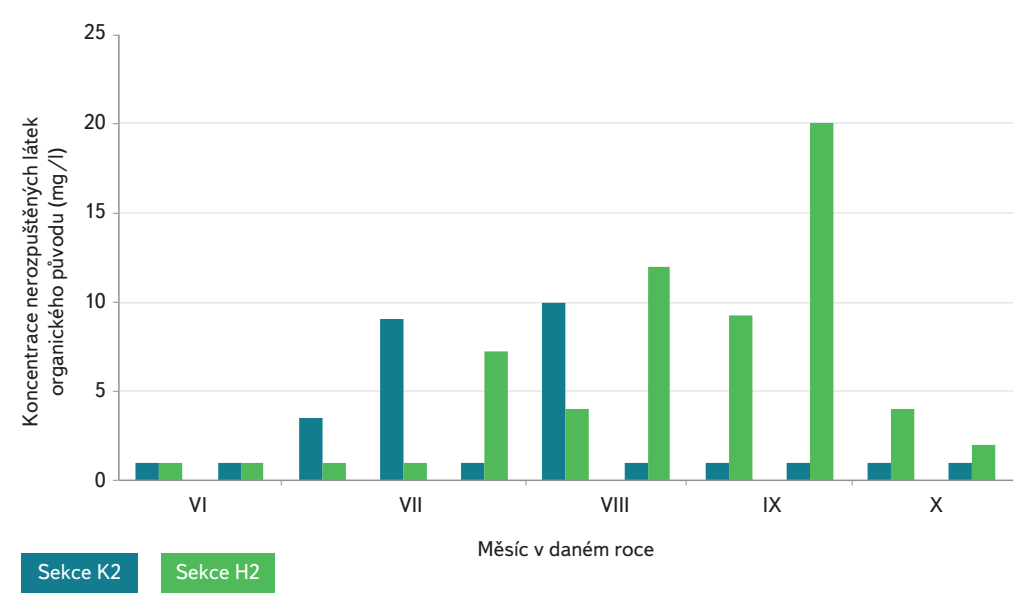

Tabulka 1. Základni statistické charakteristiky podilu organické složky v sedimentech Table 1. Basic statistical characteristics of the organic component ratio in the sediments

\begin{tabular}{ll}
$\begin{array}{l}\text { Charakteristika datového } \\
\text { souboru vzorků sedimentů }\end{array}$ & $\begin{array}{l}\text { Podíl organické } \\
\text { složky [\%] }\end{array}$ \\
\hline Střední hodnota souboru & 19,6 \\
\hline Směrodatná odchylka souboru & 11,9 \\
\hline Medián & 15,8 \\
\hline Minimum & 6,5 \\
\hline Maximum & 59,6 \\
\hline Počet hodnot v souboru & 90
\end{tabular}

Obr. 5. Rozdíl mezi organickou, spalitelnou složkou nerozpuštěných látek ve vodě modelových nádrží během roku 2018

Fig. 5. Differences between amounts of VSS in the water of the model basins during the year 2018

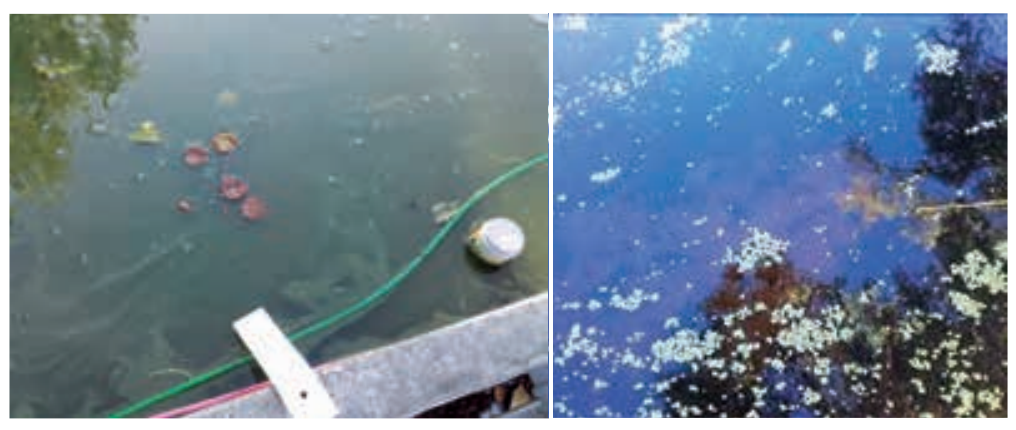

Obr. 6. Rozdíl mezi průhledností vody nádrže bez aplikace prípravku (vlevo, sinicový vodní květ) a s jeho aplikací během vegetační sezony (vpravo)

Fig. 6. Differences of the water transparency between basin without biological preparation application (left, blue algae surface film) and basin with the preparation application during vegetation period (right)

\section{VÝSLEDKY A DISKUSE}

\section{Poloprovozní modelové nádrže}

U všech čtyř sekcí poloprovozních modelů okrasných nádrží nebyly ani v průběhu sezony (červen až listopad) změřeny významné rozdíly v průběhu teploty vody (obr. 4). Naopak pH vody bylo odlišné mezi sekcemi bez prí́davku prípravku (sekce H1 a H2), kdy hodnoty pH dosahovaly až do rozmezí 9-11, a sekcemi s aplikací př́pravku, tedy K1 a K2 (obr. 4). Tento poznatek je důležitý pro prípad, že by v nádržích byly prítomné ryby. Zjištěné vysoké hodnoty $\mathrm{pH}$ v sekcích $\mathrm{H} 1$ a $\mathrm{H} 2$ by mohly způsobit výskyt nedisociované formy amoniaku toxické pro ryby. Koncentrace amoniakálního dusíku byly u modelových nádrží velmi nízké, na úrovni pod 1 mg/l, tedy toto riziko nenastalo. $\vee$ reálných podmínkách by mohly být vyšší.

Koncentrace rozpuštěného kyslíku a nasycení vody kyslíkem byly dostatečné, a to díky provzdušování vody, pohybovaly se nad hranicí 4 až 6 mg/l, dostatečnou pro násadu okrasných druhů kaprovitých ryb.

Biologický prípravek zlepšoval především vizuální kvalitu vody. Z grafu na obr. 5 je patrné, že množství suspendovaných částic ve vodě, zejména organického původu (spalitelných organických látek stanovovaných pomocí ztráty žíháním), se během vegetačního období - návštěvnické sezony roku 2018 snižovalo (bazén "H2" - bez přidání biologického prípravku, bazén „K2" - s přípravkem).

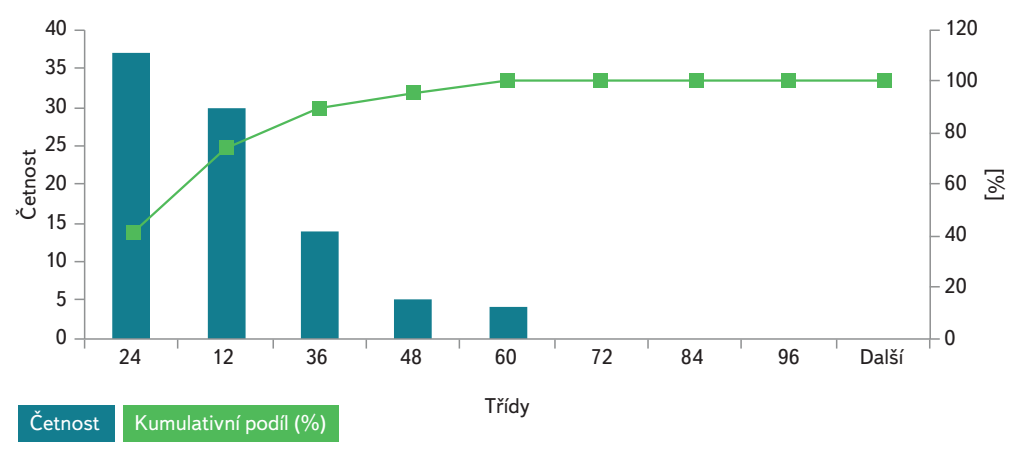

Obr. 7. Četnost sedimentů definovaných tříd ("Třídy") podílu organické složky v celkovém souboru

Fig. 7. Sediment frequency of the defined groups of organic component ratio within the whole dataset

U poloprovozní nádrže se sekcemi H2 a K2, kde byl sezonně aplikován prípravek, došlo k potlačení rozvoje vodního květu, jak je dokumentováno na obr. 6 , který zobrazuje stav sekcí K1 a K2. Podle průzkumu na konci sezony došlo také k celkové redukci usazenin na dně nádrže K2. Na začátku sledování byl do všech sekcí rozvrstven sediment přivezený z rybníka v areálu zámku Červené Poříćí (Klatovsko) převážně organického charakteru (největší zastoupení mělo opadané a usazené, částečně již rozložené listí z předchozího podzimu) o tloušțce cca $10 \mathrm{~cm}$. Sediment tohoto rybníka použitý v poloprovozním pokusu svým charakterem odpovídal průměrnému sedimentu z celého souboru 90 analyzovaných vzorků.

$\checkmark$ tabulce 1 jsou uvedeny základní statistické charakteristiky tohoto souboru dnových sedimentů pro ukazatel "ztráta žíháním“. Obsah organických látek se pohybuje ve velkém rozpětí hodnot od sedimentů převážně anorganického původu (např. splachy z komunikací, případně čisté sedimenty bez přísunu organické složky) až po sedimenty převážně organického původu (hodnota ztráty žíháním nad 40 \%). Střední hodnota souboru je cca 20 \%, což je v souladu s poznatky z průzkumů sedimentů klasických rybníků v krajině. Převážná většina lokalit má sedimenty s podílem organické složky do $24 \%$, přičemž nejčastěji se jedná o rozmezí 12-24\% (cca 35 prrípadů), následované o něco méně četnou skupinou 0-12 \% (cca 30 prrípadů) - viz obr. 7. Z uvedeného vyplývá, že potenciál využití biologických přípravků je poměrně velký, a to zejména $v$ př́ipadě lokalit, kde je opad listí a rozklad staré biomasy vodních a mokřadních rostlin rostoucích ve vodním prvku velký. Týká se i výše uvedených dvou skupin sedimentů. 

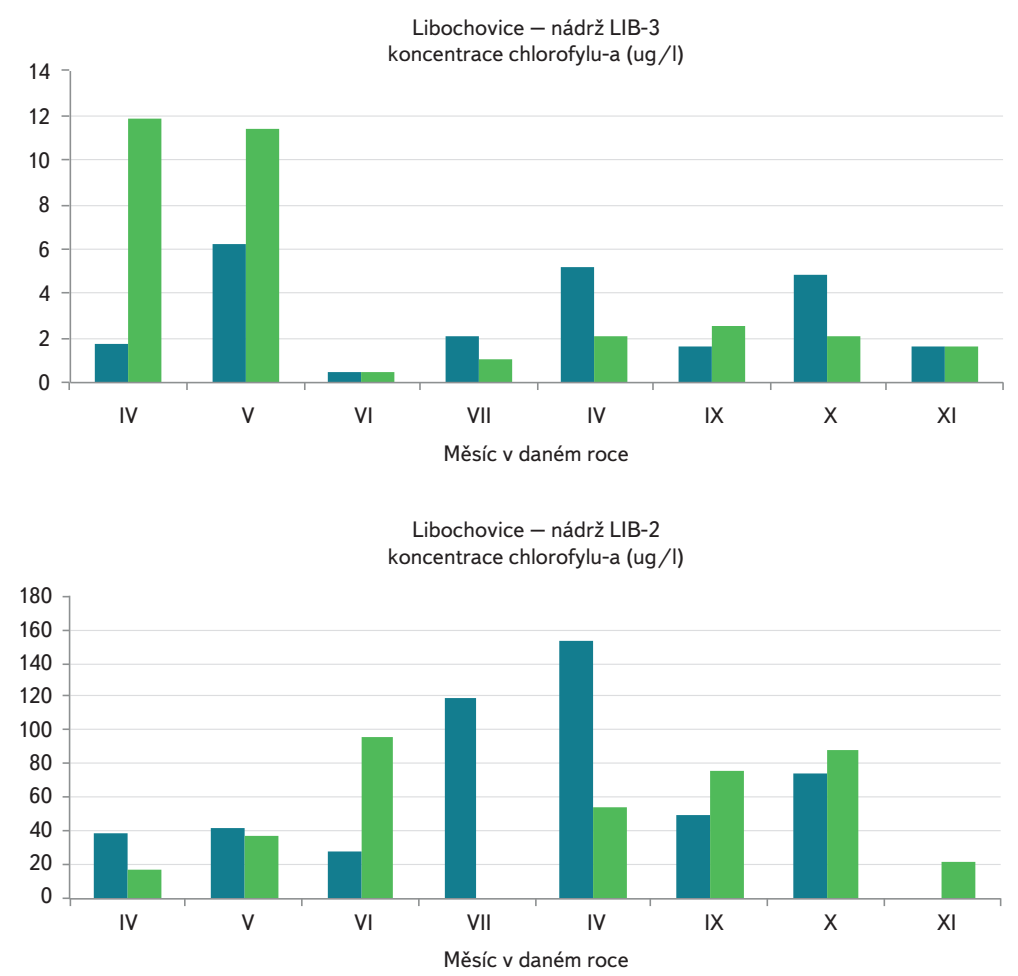

2017 2018

Obr. 8. Koncentrace chlorofylu-a v libochovických vodních prvcích během vegetační (návštěvnické) sezony 2017 (bez aplikace biologického prípravku) a sezony 2018 (s aplikací prípravku)

Fig. 8. Concentration of chlorophyll-a in the Libochovice water elements during the vegetation (visitor) seasons 2017 (without preparation adding) and 2018 (with preparation adding)

\section{Praktická zkušební aplikace biologického prípravku do vodních prvků v Libochovicích}

Během aplikace prípravku do vodních prvků v zahradě libochovického zámku nebyly výsledky tak jasné, jak je dokumentováno v prípadě poloprovozních nádrží. Pozitivní dopad aplikace biologického prípravku na zákal vody, organické suspendované pevné látky a koncentraci biomasy řas (chlorofyl-a) byl vyšší pouze v letním nejteplejším období sezony (obr. 8).

Současně je ale z obr. 9 patrné, že v sezoně 2018 bylo oproti roku 2017, kdy př́pravek nebyl aplikován, odlišné množství a složení biosestonu. Díky dávkování prípravku došlo k potlačení rozvoje sinic.

Kvalita životního prostředí může být ovlivněna aplikací časem ověřených i aktuálně používaných postupů a kontrolou biologických procesů. V současné době používané postupy zahrnuji recirkulaci vody a filtraci, které jsou více použitelné pro formální vodní prvky. Podrobnosti o těchto řešeních pro tyto formální vodní prvky jsou uvedeny napríklad v príručce [3]. Tyto metody zahrnují manipulaci s vodou, její výměnu nebo zajištění jejího dostatečného průtoku a ž̌edění jejího znečištění. To jsou postupy, které lze použít pro formální i neformální vodní prvky. $\vee$ některých prípadech je možné změnit zdroj vody $\vee$ rámci rekonstrukce. $V$ prípadě menších vodních prvků je možné ovlivnit nebo omezit eutrofizaci vody, zákal, zbarvení vody, rozvoj vodního květu a nadměrný rưst biomasy vláknitých řas či biofilmu použitím chemických produktů pro úpravu nebo dezinfekci vody, nebo ruční údržbou, či jejich kombinací (ruční odstranění a odvoz odumřelé anebo ošetřené biomasy - viz obr. 10). To je např́ílad pravidelně (přibližně $1 \times 3$ týdny) prováděno během letní sezony u vybraných
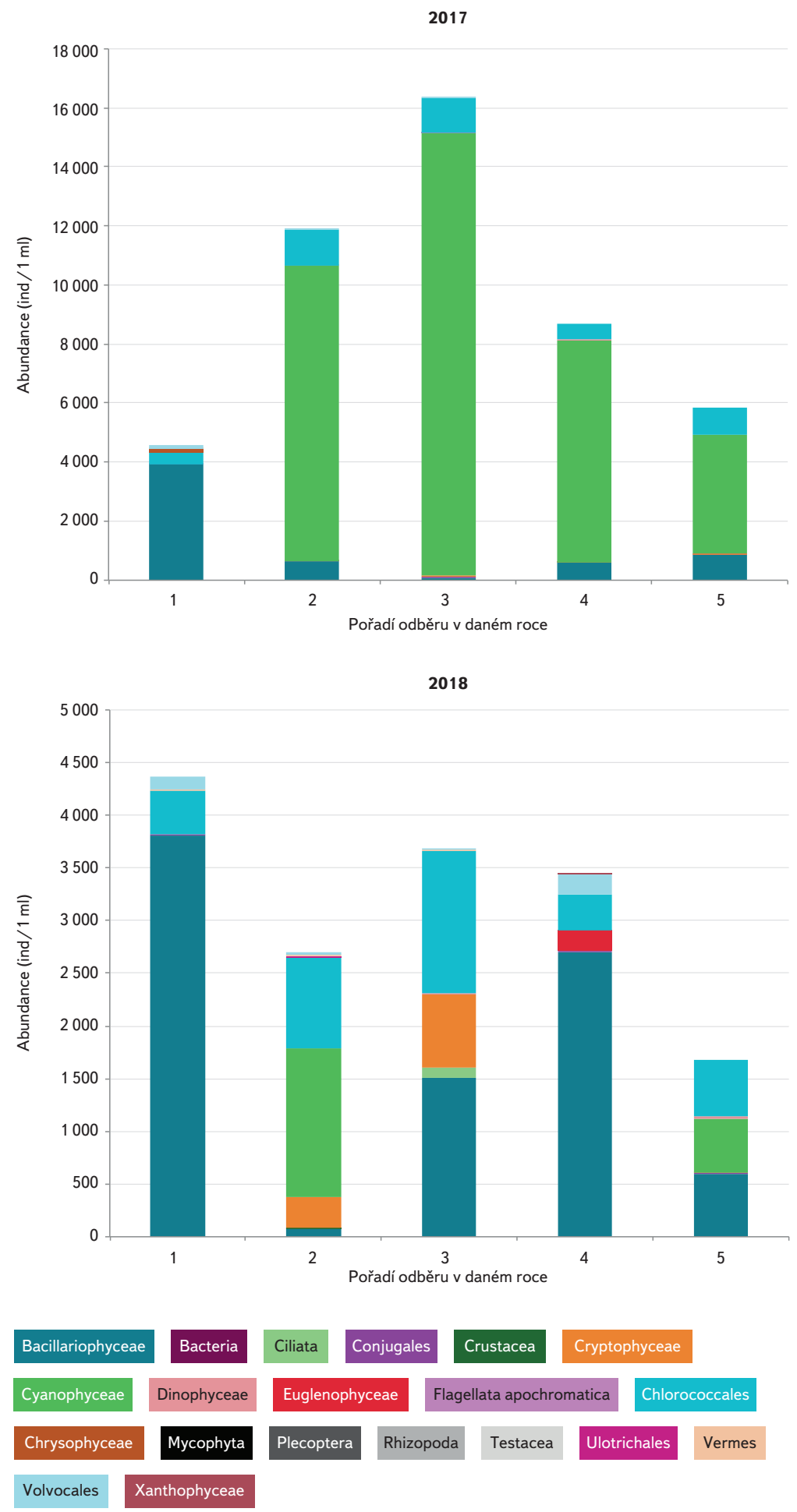

Obr. 9. Složení biosestonu nádrže LIB-2

Fig. 9. Bioseston composition of the LIB-2 basin

formálních mělkých vodních prvků v areálu Hellbrunn u Salcburku (Rakousko). Zde jsou metlami ručně uvolňovány dnové biologické usazeniny a nárosty (biofilmu) z povrchu štěrkového dna. Jejich odnos a zachycení na odtokovém sítu je zajištěn bud' průtočností nádrže, nebo proplachem hadicí.

Mezi nové postupy, jejichž používání se postupně rozšiřuje, patří využití biochemie a biotechnologií založených na aplikaci bakteriálně-enzymatických prípravků, které mohou př́znivě ovlivnit složení sedimentů a jejich množství [12]. 


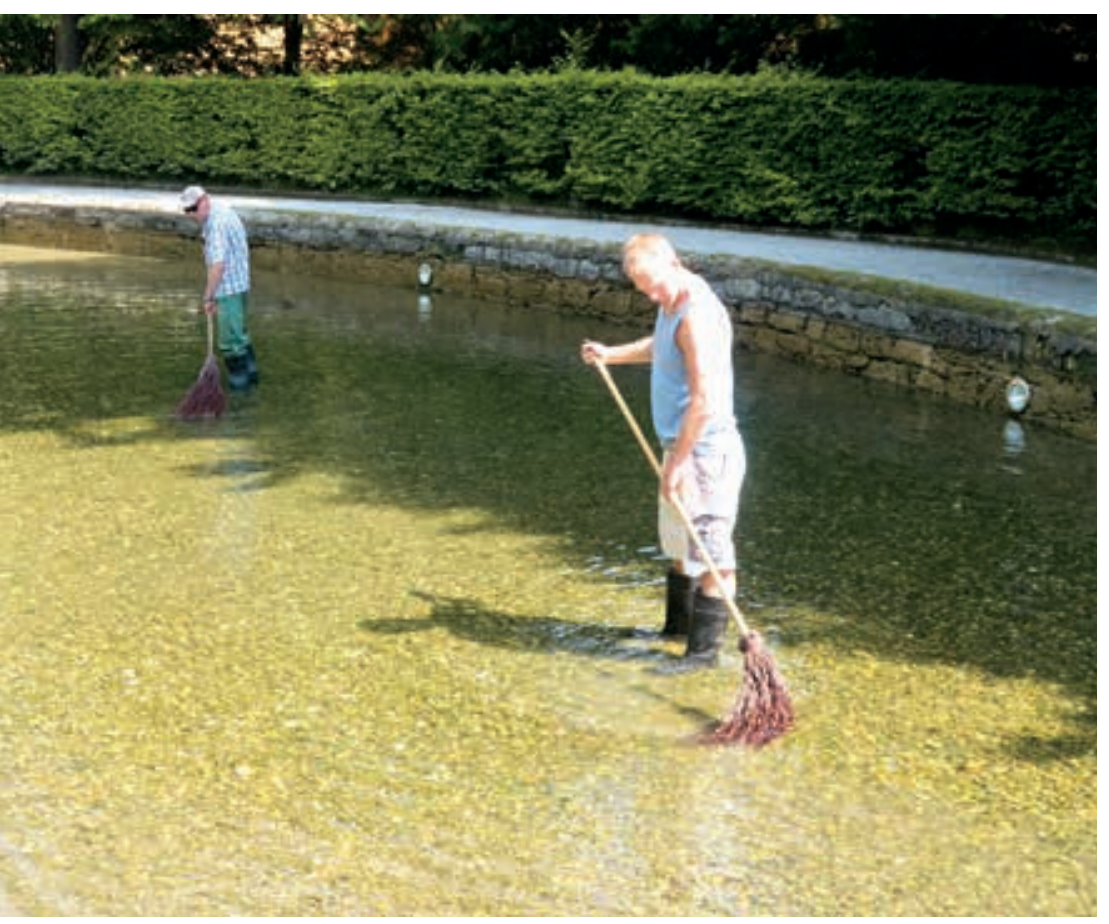

Obr. 10. Ruční čištění štěrkového dna okrasných bazénů od řasového biofilmu (Hellbrunn, Rakousko)

Fig. 10. Manual cleaning of gravel bottom of ornamental pools from algal biofilm (Hellbrunn, Austria)

Vlastnosti přípravků a jejich účinnost jsou studovány pomocí mikrobiologických metod a také identifikace změn v koncentracích indikátorů kvality vody (zejména obsahu živin) a složení biosestonu (s ohledem na konkurenci mezi bakteriemi a řasami) [13]. Tyto zahraniční poznatky potvrzuje i naše provedená studie.

\section{ZÁVĚR}

Vodní prvky představují významnou součást prostředí kulturních památek a památkových zón a rezervací. Pro plnění požadovaných funkcí, které mohou zahrnovat společenské, ale i environmentální funkce, je nutné, aby byly v odpovídajícím cílovém stavu. Tento stav zahrnuje jak stavebně-technický stav, tak i kvalitativní stav.

Kvalita vody v malých nádržích a rybnících se může měnit dvěma směry. Pozitivním, v prípadě silného organického zatížení přitoku, kdy pomocí samočistících procesů dochází k dočištění vody. Naopak negativním směrem v př́ipadě neznečištěného př́toku a chovu ryb v nádrži [15, 16]. V práci [17] autoři identifikovali mezi hlavními tlaky pưsobícími negativně na malé vodní nádrže vnos znečištění odpadními vodami a drenážními systémy. Mezi dalši klíčové tlaky zařadili chov ryb a rybářství. Velmi významně působí i sousedství nádrží se zemědělsky obhospodařovanou půdou. Také v př́padě námi sledovaných lokalit jsou tyto tlaky hlavními príčinami ohrožení s následkem nevyhovujícího stavu, včetně nevhodného estetického působení, které je důležitým faktorem vnímání návštěvníky památkově chráněných objektů, areálů a území.

Prezentované poznatky ze studie ukázaly, že biologické bakteriální enzymatické přípravky a chemické prípravky šetrné k životnímu prostředí využitelné pro srážení fosforu, oxidaci organických látek a k eliminaci biomasy vláknitých řas mohou zlepšit vlastnosti vodního prostredí u takových prvků, jako jsou menší bazény, okrasné bazény a nádrže, včetně potlačení vývoje vodního květu. Jako ideální se jeví kombinace aplikace těchto prípravků a zejména zahájení jejich aplikace včas, preventivně a po celou sezonu. To umožní předcházet rozvoji negativního stavu kvality vodního prostředí. Zlepšení a/nebo udržení stabilního stavu vodního prostředí během sezony může být důležitým prvkem v jejich atraktivitě pro návštěvníky.

\section{Poděkování}

Výsledky byly získány za finanční podpory projektu DG16P02M032 z výzvy NAKI II Ministerstva kultury ČR „Neinvazivní a šetrné postupy řešení kvality prostředí a údržby vodnich prvků v rámci památkové péče".

\section{Literatura}

[1] PACÁKOVÁ-HOŠŤÁLKOVÁ, B. a kol. Zahrady a parky v Čechách, na Moravě a ve Slezsku. Praha: Nakladatelství Libri, 2004, 526 s.

[2] Cultural (garden) heritage as a focal point for sustainable tourism. [online] [cit. 30. 4. 2018]. Dostupný z: http://www.southeast-europe.net/en/projects/approved_projects/?id=142

[3] JANÁL, J., KŘESADLOVÁ, L., OBŠIVAČ, J., OLŠAN, J., ROZKOŠNÝ, M. a ŽABIČKA, Z. Formální vodni prvky v památkách zahradního umění. 87. svazek edice Odborné a metodické publikace. Národní památkový ústav, Praha, 2016, 151 s. ISBN 978-80-7480-073-3.

[4] PECHAR, L. Long-term changes in fish pond management as an unplanned ecosystem experiment: importance of zooplankton structure, nutrients and light for species composition of cyanobacterial blooms. Water Science \& Technology, Vol. 1995, No. 32, p. 187-196.

[5] POTUŽÁK, J. a DURAS, J. Výlov rybníků - kritické období z pohledu emisí fosforu? Vodárenská biologie, Praha, 2012, s. 52-59.

[6] CASSAR, M. and PENDER, R. The impact of climate change on cultural heritage: evidence and response. 2005. [online] [cit. 30. 4. 2018]. Dostupný z: http://discovery.ucl.ac.uk/5059/1/5059.pdf

[7] AKCIL, A. et al. A review of approaches and techniques used in aquatic contaminated sediments: metal removal and stabilization by chemical and biotechnological processes. Journal of Cleaner Production, Vol. 2015, No. 86, p. 24-36.

[8] FORSNER, U. and APITZ, S.E. State of the art in the USA sediment remediation: U.S. In: Focus on Capping and Monitored Natural Recovery Fourth International Battelle Conference on Remediation of Contaminated Sediments, 2007, Vol. 7, p. 351-358.

[9] RULKENS, W. Introduction to the treatment of polluted sediments. Rev. Environ. Sci. Bio/Technol, Vol. 2005, No. 4, p. 213-221.

[10] BORTONE, G. et al. Synthesis of the SedNet work package 4 outcomes. J. Soils Sediments, Vol. 2004, No. 4, p. 225-232.

[11] RONTANI, J. F. et al. Degradation state of organic matter in surface sediments from the Southern Beaufort Sea: a lipid approach. Biogeosciences, Vol. 2012, No. 9, p. 3513-3530.

[12] HAAS, Z.D. Sludge Controlling Bacteria within a Pond Ecosystem. 2015. [online] [cit. 30. 4. 2018]. Dostupný z: https://naturalake.com/wp-content/uploads/2014/09/WLPR-Study-PDF.pdf

[13] ALVAREZ, S. and GUERRERO, M. C. Enzymatic activities associated with decomposition of particulate organic matter in two shallow ponds. Soil Biology \& Biochemistry, Vol. 2000, No. 32, p. 1941-1951.

[14] ŽÁKOVÁ, Z. a MLEJNKOVÁ, H. Porovnání výsledků stanovení trofického potenciálu vody získaných mikrometodou dle TNV 757741 a standardisovanou metodou. Czech Psychology, Olomouc, 2001, s. 107-112.

[15] ROZKOŠNÝ, M. a kol. Vliv rybníků na vodní ekosystémy recipientů jižní Moravy. VTEI, 2011, roč. 53, č. 1.

[16] VŠETIČKOVÁ, L. et al. Effects of semi-intensive carp pond farming on discharged water quality. Acta Ichthyologica et Piscatoria, Vol. 2012, No. 42 (3), p. 223-231.

[17] JUSZCZAK, R. and KĘDZIORA, A. Threats to and Deterioration of Small Water Reservoirs Located within Wyskoć Catchment. Polish Journal of Environmental Studies, Vol. 2003, No. 12 (5), p. 567-573. 


\section{Autoři}

Ing. Miloš Rozkošný, Ph.D.'

凶milos.rozkosny@vuv.cz

Ing. Josef Kratina, Ph.D. ${ }^{2}$

凶josef.kratina@vuv.cz

Ing. Hana Hudcová, Ph.D.'

凶hana.hudcova@vuv.cz

Ing. Pavel Sedláček ${ }^{1}$

凶pavel.sedlacek@vuv.cz

'Výzkumný ústav vodohospodářský T. G. Masaryka, v. v. i., pobočka Brno ${ }^{2}$ Výzkumný ústav vodohospodářský T. G. Masaryka, v. v. i., Praha

Příspěvek prošel lektorským řízením.

\section{FIDINGS FROM TESTING OF SELECTED BIOCHEMICAL PRODUCTS TO THE HERITAGE SITES WATER ELEMENTS ENVIRONMENT ADJUSTMENT}

\section{ROZKOSNY, M.'; KRATINA, J. ${ }^{2}$; HUDCOVA, H.'; SEDLACEK, P. ${ }^{1}$}

'TGM Water Research Institute, p.r.i., Brno Branch

${ }^{2}$ TGM Water Research Institute, p.r.i., Prague

Keywords: cultural heritage - historical garden -

water elements - biological preparation - water quality

The article is focus on the presentation of knowledge from testing of selected biochemical preparations for the treatment of the environment of water elements of historical gardens and parks and cultural monuments. The aim of the study was experimentally evaluate the benefits and risks of application of these products with a view to improving water quality, reducing the development of algae and cyanobacteria in eutrophic conditions and reducing the volume of bottom sediment. A set of pilot models of ornamental basins was use for the study and with direct application on real water elements of the chateau garden in the Libochovice town. The findings show that by regularly applying selected and suitable biochemical products, preferably from the beginning of the season, it is possible to reach the appropriate quality of the aquatic environment. It is valid especially for small pools and reservoirs. Part of the work was also an analysis of a set of sediment samples to determine the potential use of preparations on a larger scale. The potential to improve organic sediment amount and content was confirm. 